A N N A L ES

UNIVERSITATIS MARIAE CURIE-SKŁODOWSKA

LUBLIN - POLONIA

VOL. LXII, 2

SECTIO G

2015

ANNA KOSUT

\title{
Równość i sprawiedliwość w dostępie do zatrudnienia
}

Equality and Justice in Access to Employment

W piśmiennictwie zasadnie wskazuje się, że wśród wartości, które powinno chronić (realizować) prawo pracy znajdują się między innymi równość i sprawiedliwość1. Wartości te mają swoje zakotwiczenie w Konstytucji $\mathrm{RP}^{2}$, a ich znaczenie dla urzeczywistnienia statuowanych przez ustawę zasadniczą wolności i praw socjalnych człowieka jest niepodważalne. Wśród tych wolności i praw swoje miejsce ma również wolność pracy, której treścią, w tzw. pozytywnym aspekcie tej zasady ${ }^{3}$, jest wolność wyboru i wykonywania zawodu oraz wyboru miejsca pracy (art. 65 ust. 1 Konstytucji).

Według Trybunału Konstytucyjnego wolność pracy oznacza „brak ograniczeń polegających na uniemożliwieniu wykonywania określonego zawodu czy zatrudnienia"4 lub - inaczej ujmując - „generalny zakaz adresowany do władz publicznych wprowadzania ograniczeń w swobodnym decydowaniu przez jednostkę o podjęciu, kontynuowaniu i zakończeniu pracy w określonym zawodzie, o miejscu i rodzaju wykonywanej pracy oraz wyborze pracodawcy"s.

Za gwarancję możliwości korzystania z tak rozumianej wolności pracy uznać należy niewątpliwie równy i sprawiedliwy dostęp do zatrudnienia ${ }^{6}$. Tej właśnie

1 T. Liszcz, $W$ sprawie sprawiedliwości w prawie pracy, [w:] Aksjologiczne podstawy prawa pracy i ubezpieczeń społecznych, pod red. M. Skąpskiego, K. Ślebzaka, Poznań 2014, s. 111.

2 Ustawa z dnia 2 kwietnia 1997 roku (Dz.U., nr 78, poz. 483 z późn. zm.).

3 Dwa aspekty zasady wolności pracy wyróżnił TK m.in. w wyrokach: z dnia 26 kwietnia 1999 roku, K 33/98, OTK 1999, nr 4, poz. 71; z dnia 23 czerwca 1999 roku, K 30/98, OTK 1999, nr 5, poz. 101. Aspekt negatywny tej zasady formułuje art. 65 ust. 2 Konstytucji.

4 Wyrok TK z dnia 13 czerwca 2000 roku, K 12/99, OTK ZU 2000, nr 5, poz. 137.

5 Wyrok TK z dnia 24 stycznia 2001 roku, SK 30/99, OTK ZU 2001, nr 1, poz. 3.

6 W niniejszym opracowaniu ,zatrudnienie” oznacza świadczenie pracy w ramach stosunku pracy. Inne, szersze znaczenie pojęcie to ma jedynie w części odnoszącej się do unormowań zawar- 
materii dotyczy niniejsze opracowanie, które, zważywszy na obszerność i wielopłaszczyznowość tematu, odnosi się do wybranych aspektów analizowanej problematyki.

Przed przejściem do bardziej szczegółowych rozważań warto choć kilka ogólnych uwag poświęcić znaczeniu pojęć „równość” i „sprawiedliwość” jako zasad konstytucyjnych oraz relacjom między tymi zasadami. Sięgając ponownie do poglądów Trybunału Konstytucyjnego, należy w odniesieniu do zasady równości odwołać się do powszechnie znanego i wielokrotnie cytowanego w piśmiennictwie wyroku z dnia 9 marca $1988 \mathrm{roku}^{7}$. Zdaniem Trybunału ,zasada równości wobec prawa (równości w prawie) polega na tym, że wszystkie podmioty prawa (adresaci norm prawnych) charakteryzujące się daną cechą istotną (relewantną) w równym stopniu mają być traktowane równo. A więc według jednakowej miary, bez zróżnicowań zarówno dyskryminacyjnych, jak i faworyzujących". Nie oznacza to jednak bezwzględnego egalitaryzmu - równość to bowiem także akceptacja różnego traktowania przez prawo różnych podmiotów, $\mathrm{z}$ tym jednak, że to różne traktowanie powinno być uzasadnione. Równość wobec prawa to również zasadność wybrania takiego a nie innego kryterium zróżnicowania podmiotów prawa ${ }^{8}$. Zróżnicowanie to jest dopuszczalne, o ile jest usprawiedliwione, co prowadzi do konkluzji, że reguła równości musi być rozpatrywana w powiązaniu z zasadą sprawiedliwości.

To, czym jest sprawiedliwość, od wieków stanowi jeden z zasadniczych problemów badawczych w filozofii, socjologii czy teorii prawa. Ta arystotelesowska najwyższa z cnót moralnych (etycznych), przez J. Rawlsa uznana za pierwszą cnotę społecznych instytucji ${ }^{9}$, ma swoje miejsce także w Konstytucji RP. Na sprawiedliwość jako wartość uniwersalną, konieczną zasadę życia społecznego powołuje się preambuła, zaś w art. 2 ustawy zasadniczej pojawia się formuła sprawiedliwości społecznej. To właśnie do zasady sprawiedliwości społecznej ${ }^{10}$ wielokrotnie odwołuje się w swych orzeczeniach Trybunał Konstytucyjny ${ }^{11}$, łącząc ją z zasadą

tych w ustawie $\mathrm{z}$ dnia 20 kwietnia 2004 roku o promocji zatrudnienia i instytucjach rynku pracy (t.j. Dz.U. z 2013 roku, poz. 674 z późn. zm., zwana dalej: ustawą o promocji zatrudnienia). Na gruncie tej ustawy oznacza ono bowiem wykonywanie pracy na podstawie stosunku pracy, stosunku służbowego oraz umowy o pracę nakładczą.

7 U 7/87, OTK 1988, nr 1, poz. 1.

8 Wyrok TK z dnia 11 października 1989 roku, K 4/89, OTK 1989, poz. 6, s. 108.

9 J. Rawls, Teoria sprawiedliwości, Warszawa 1994, s. 13.

10 W piśmiennictwie podkreśla się, że TK konsekwentnie powołuje się na zasadę sprawiedliwości społecznej, gdy tymczasem art. 2 Konstytucji stanowi o zasadach sprawiedliwości społecznej. Zob. A. Bura, Pojmowanie sprawiedliwości w orzecznictwie Trybunału Konstytucyjnego, „Przegląd Sejmowy" 2001, nr 2, s. 42 (przypis 4) i 56.

11 Zob. ibidem, s. 41 i n. 
poszanowania godności człowieka (art. 30 Konstytucji) oraz z zasadą równości (art. 32 Konstytucji).

Związek zasad równości i sprawiedliwości Trybunał podkreślał wielokrotnie, choć nie zawsze w taki sam sposób ustalał relacje między nimi. Równość traktowana jest bowiem niekiedy jako zasada pochodna od zasady sprawiedliwości lub jej element, niekiedy sprawiedliwość i równość kumulują się, a niekiedy sprawiedliwość jest czymś nadrzędnym w stosunku do równości ${ }^{12}$.

Wydaje się, że ustalenie relacji między tymi zasadami zależy od tego, którą formułą sprawiedliwości posługuje się Trybunał Konstytucyjny. Zasada sprawiedliwości występuje bowiem w orzecznictwie TK w dwojakiej postaci: w ujęciu formalnym oraz jako skonkretyzowana formuła ${ }^{13}$.

Uznanie sprawiedliwości formalnej jako zasady działania, w myśl której osoby należące do tej samej kategorii istotnej powinny być traktowane jednakowo, jest identyczne $z$ określeniem zasady równości wobec prawa i dzieje się tak nie bez przyczyny - idea równej miary leży u samych podstaw sprawiedliwości ${ }^{14}$. Natomiast sprawiedliwość konkretna i jej formuły („każdemu według...”) pojawiają się w orzecznictwie Trybunału wtedy, gdy powołuje się on na zasadę sprawiedliwości społecznej.

Zasada sprawiedliwości społecznej odnosi się do złożonej formuły sprawiedliwości konkretnej, gdzie zakwalifikowanie jakiegoś rozstrzygnięcia jako odpowiadającego jej wymogom powoduje konieczność rozważenia nie jednej, a wielu prostych formuł konkretnych ${ }^{15}$. Wypadkowa owych formuł tworzy właściwy wzorzec orzekania, którego zastosowanie pełni w świetle orzecznictwa Trybunału jedną podstawową funkcję - korekty zasady równości na rzecz podmiotów znajdujących się w najtrudniejszej sytuacji społecznej ${ }^{16}$. W wyroku z dnia 28 maja 1986 roku $^{17}$ Trybunał Konstytucyjny uznał zasadę sprawiedliwości społecznej właśnie jako korektę zasady równości na korzyść obywateli znajdujących się w najtrudniejszej sytuacji ekonomicznej. Ten korygujący aspekt zasady sprawiedliwości społecznej widoczny jest także w orzeczeniach Trybunału zapadłych po 1989 roku. Ma ona więc w tych przypadkach prymat nad zasadą równości, niekiedy również przed innymi zasadami konstytucyjnymi ${ }^{18}$.

12 Zob. J. Nowacki, Sprawiedliwość a równość w orzecznictwie Trybunału Konstytucyjnego, [w:] W kręgu zagadnień konstytucyjnych. Profesorowi Eugeniuszowi Zwierzchowskiemu w darze, pod red. M. Kudeja, Katowice 1999, s. 87.

13 M. Kordela, Zarys systemu aksjologicznego w orzecznictwie Trybunatu Konstytucyjnego, „Studia Prawnicze” 2000, nr 1-2, s. 81.

14 Ibidem, s. 82.

15 Z. Ziembiński, Sprawiedliwość społeczna jako pojęcie prawne, Warszawa 1996, s. 58.

16 M. Kordela, op. cit., s. 84.

17 U 1/86, OTK 1986, poz. 2, s. 49.

18 A. Bura, op. cit., s. 56. 
$\mathrm{Na}$ gruncie Kodeksu pracy zasadę równości pracowników w dziedzinie zatrudnienia, nazywaną też zasadą równego traktowania pracowników lub równych praw dla pracowników wykonujących takie same obowiązki, formułuje art. 112. Jak widać, sposób jej określania nie jest jednolity, wątpliwości budzi ponadto relacja między tą zasadą a zasadą niedyskryminacji (zakazu dyskryminacji). Odsyłając do bogatej literatury przedmiotu ${ }^{19}$, należy jedynie wskazać, że w niniejszym opracowaniu określenia „równe traktowanie” i „niedyskryminowanie” bądź „,naruszenie zasady równego traktowania” i „dyskryminowanie” stosowane są zamiennie. Tego rodzaju praktyka, znana choćby $\mathrm{z}$ regulacji zawartych $\mathrm{w}$ prawie unijnym ${ }^{20}$, stanowi niewątpliwie pewne uproszczenie, gdyż nie zawsze naruszenie zasady równego traktowania jest dyskryminacją. Wystąpi ona bowiem tylko wtedy, gdy pracownicy wypełniający jednakowo swe obowiązki traktowani są nierówno ze względu na przyczyny (kryteria) określone w art. $18^{3 a}$ k.p. Jeśli natomiast nierówność w takiej sytuacji nie jest podyktowana zakazanymi kryteriami, mamy do czynienia wyłącznie z naruszeniem zasady równych praw (równego traktowania) ${ }^{21}$.

Zasady równych praw pracowników (art. $11^{2} \mathrm{k} . p$.) oraz zakazu dyskryminacji (art. $11^{3}$ k.p.) znalazły swoje uszczegółowienie w unormowaniach rozdziału IIa działu pierwszego Kodeksu pracy, zatytułowanego „Równe traktowanie w zatrudnieniu". Określający sfery (obszary) zatrudnienia, w jakich pracodawca jest zobowiązany do równego traktowania pracowników art. $18^{3 \mathrm{a}} \S 1$ k.p. odnosi tę zasadę do nawiązania stosunku pracy (a więc dostępu do zatrudnienia ${ }^{22}$ ), rozwią-

19 Zob. m.in.: Z. Góral, O kodeksowym katalogu zasad indywidualnego prawa pracy, Warszawa 2011, s. 153 i n.; A. Sobczyk, Prawo pracy w świetle Konstytucji RP, t. 1, Warszawa 2013, s. 225-260; B. Wagner, Zasada równego traktowania i niedyskryminacji pracowników, „Praca i Zabezpieczenie Społeczne" 2002, nr 3, s. 2; M.J. Zieliński, Zasada równego traktowania a zakaz dyskryminacji w prawie pracy, „Praca i Zabezpieczenie Społeczne”2013, nr 8, s. 25; J. Boruta, Zakaz dyskryminacji w zatrudnieniu - nowa regulacja prawna, „Praca i Zabezpieczenie Społeczne” 2004, nr 2, s. 2; T. Zieliński, G. Goździewicz, [w:] Kodeks pracy. Komentarz, pod red. L. Florka, Warszawa 2011, s. 84 i n.; K. Rączka, [w:] M. Gersdorf, K. Rączka, M. Raczkowski, Kodeks pracy. Komentarz, Warszawa 2014, s. 63 i n.; W. Perdeus, [w:] Kodeks pracy. Komentarz, pod red. K.W. Barana, Warszawa 2014, s. 97 i n.

${ }^{20}$ Zob. L. Florek, Europejskie prawo pracy, Warszawa 2003, s. 65. Na gruncie polskich unormowań do zamieszania terminologicznego przysłużył się w pewnym sensie sam ustawodawca, nadając rozdziałowi IIa działu pierwszego Kodeksu pracy tytuł „Równe traktowanie w zatrudnieniu”, gdy tymczasem przedmiotem zawartych tam regulacji jest zakaz dyskryminacji. Por. M. Tomaszewska, [w:] Kodeks pracy. Komentarz, pod red. K.W. Barana, s. 128.

${ }_{21}$ Tak SN w wyroku z dnia 2 października 2012 roku, II PK 82/12, LEX nr 1243029; podobnie w wyroku z dnia 18 września 2008 roku, II PK 27/08, OSNP 2010, nr 3-4, poz. 41.

${ }_{22}$ Zob. K. Rączka, op. cit., s. 89. 
zania stosunku pracy, kształtowania warunków zatrudnienia, awansu i dostępu do szkoleń zawodowych.

Wyliczenie to należy uzupełnić o wynikający z przepisów ustawy o promocji zatrudnienia nakaz równego traktowania bezrobotnych i osób poszukujących pracy w zakresie korzystania z pośrednictwa pracy. Jest to usługa rynku pracy, która niewątpliwie ma ścisły związek z dostępem do zatrudnienia, ponieważ jej istotą jest prowadzenie działań sprzyjających zatrudnieniu pracownika ${ }^{23}$.

Ogólną regułę dotyczącą równego traktowania w dostępie i korzystaniu z usług rynku pracy oraz instrumentów rynku pracy zawiera art. 2a ustawy o promocji zatrudnienia, natomiast zasadę równości prowadzenia pośrednictwa pracy statuuje art. 36 ust. 4 pkt 3 tej ustawy. Jej istotą jest obowiązek realizowania omawianej usługi, czyli pomocy w znalezieniu zatrudnienia lub innej pracy zarobkowej wszystkim bezrobotnym lub poszukującym pracy, bez względu na wymienione w tym przepisie kryteria (płeć, wiek, niepełnosprawność, rasę, religię, narodowość, przekonania polityczne, przynależność związkową, pochodzenie etniczne, wyznanie lub orientację seksualną).

Wskazana tu regulacja ma niewątpliwie swoje zakotwiczenie w aktach ponadnarodowych. Już w zaleceniu MOP nr 83 z 1948 roku dotyczącym organizacji służby zatrudnienia była mowa o unikaniu przez te służby, przy kierowaniu pracowników na wolne miejsca pracy, „,yskryminowania poszukujących pracy ze względu na rasę, kolor skóry, płeć lub przekonania" ${ }^{24}$. Natomiast Konwencja MOP nr 111 z 1958 roku, dotycząca dyskryminacji w zakresie zatrudnienia i wykonywania zawodu ${ }^{25}$, nakładała na państwa, które ją ratyfikowały, zobowiązanie do ustalenia i prowadzenia polityki popierającej równość szans i traktowania w dziedzinie zatrudnienia między innymi w działalności urzędów pośrednictwa pracy podlegających kontroli jakiejś władzy państwowej ${ }^{26}$.

Antydyskryminacyjne dyrektywy unijne ${ }^{27}$ nie wskazują aż tak dobitnie jak akty MOP na objęcie ich zakresem pośrednictwa pracy. Jednakże przewidziany

23 Jest to szersze znaczenie pośrednictwa pracy, w literaturze wyróżnia się również pośrednictwo pracy sensu stricto, rozumiejąc przez nie dostarczenie pracownikowi miejsca pracy, a pracodawcy - pracownika. Zob. M. Włodarczyk, [w:] Ustawa o promocji zatrudnienia i instytucjach rynku pracy. Praktyczny komentarz, pod red. Z. Górala, Warszawa 2011, s. 238.

24 Zob. K. Serafin, Zasada równego traktowania w zakresie dostępu do ustug i instrumentów rynku pracy, [w:] Bezrobocie i polityka zatrudnienia, pod red. Z. Górala, Warszawa 2013, s. 124.

25 Dz.U. z 1961 roku, nr 42, poz. 218.

$26 \mathrm{~W}$ odniesieniu do prywatnych biur pośrednictwa pracy stosowne regulacje $\mathrm{z}$ tego zakresu znalazły się w Konwencji MOP nr 181 z 1997 roku.

27 Dyrektywa 2000/43/WE z dnia 29 czerwca 2000 roku wdrażająca zasadę równego traktowania bez względu na pochodzenie rasowe lub etniczne; dyrektywa 2000/78/WE z dnia 27 listopada 2000 roku ustanawiająca ogólne ramy równego traktowania w zakresie zatrudnienia i wykonywania zawodu; dyrektywa 2006/54/WE z dnia 5 lipca 2006 roku w sprawie wprowadzenia w życie zasady równości szans oraz równego traktowania kobiet i mężczyzn w dziedzinie zatrudnienia i pracy. 
w nich nakaz zapewnienia równego dostępu do zatrudnienia należy niewątpliwie rozumieć szeroko, o czym świadczy objęcie ochroną wynikającą z dyrektyw równościowych między innymi dostępu do „poradnictwa, szkoleń i doskonalenia zawodowego oraz przekwalifikowania"28.

Zarówno prawo ponadnarodowe, jak i polskie nie nadają zasadzie równego traktowania na omawianej tu płaszczyźnie bezwzględnego charakteru. Dopuszczalne jest bowiem różnicowanie statusu bezrobotnych w zakresie korzystania z usług rynku pracy, gdyż nie wszystkie kategorie osób pozostających poza zatrudnieniem są zagrożone bezrobociem w równym stopniu. Dyferencjacja bezrobotnych w tym przypadku polega przede wszystkim na uprzywilejowaniu w zakresie otrzymania w określonym ustawą o promocji zatrudnienia czasie od rejestracji lub utraty prawa do zasiłku dla bezrobotnych propozycji zatrudnienia lub innej pracy zarobkowej ${ }^{29}$. Dotyczy to bezrobotnych do 25. roku życia oraz bezrobotnych będących w szczególnej sytuacji na rynku pracy, którzy korzystają ze świadczeń pomocy społecznej.

Natomiast wszystkie kategorie bezrobotnych znajdujących się w szczególnej sytuacji na rynku pracy (art. 49 ustawy o promocji zatrudnienia) mogą stać się beneficjentami umowy zawartej przez starostę z agencją zatrudnienia. Przedmiotem tej umowy jest doprowadzenie do zatrudnienia bezrobotnego na okres co najmniej 6 miesięcy, w pełnym wymiarze czasu pracy (art. $61 \mathrm{~b}$ ustawy o promocji zatrudnienia).

Wyróżnienie grup bezrobotnych będących w szczególnej sytuacji na rynku pracy, co nastąpiło w 2004 roku, i przyznanie im szczególnych uprawnień nie wzbudziło większych zastrzeżeń w kontekście zasady równego traktowania bezrobotnych. Pewne wątpliwości w tym zakresie budzi natomiast wprowadzone do ustawy o promocji zatrudnienia w 2014 roku $^{30}$ profilowanie pomocy dla bezrobotnych. W ramach wyróżnionych przez ustawę trzech profili pomocy przewidziano różny zakres usług $\mathrm{i}$ instrumentów, jakie mogą zostać zastosowane w odniesieniu do osoby bezrobotnej ${ }^{31}$. W zależności więc od tego, jaki profil zostanie ustalony dla bezrobotnego, ma on prawo do skorzystania wyłącznie z określonych, przypisanych dla tego profilu środków i form wsparcia.

Szerzej zob. K. Ślebzak, Antydyskryminacyjne prawo Unii Europejskiej w dziedzinie zatrudnienia w orzecznictwie TSUE - zakres i podstawowe pojęcia, „Praca i Zabezpieczenie Społeczne” 2013, nr 9, s. 2 i n.

28 K. Serafin, op. cit., s. 126; L. Florek, Europejskie prawo pracy, Warszawa 2003, s. 82.

29 Przewidujący to uprawnienie art. 50 tej ustawy wskazuje na jeszcze inne formy pomocy, które można zakwalifikować do szeroko rozumianego pośrednictwa, a więc działań sprzyjających zatrudnieniu bezrobotnego (takich jak szkolenie, staż, prace interwencyjne, roboty publiczne).

30 Ustawa z dnia 14 marca 2014 roku o zmianie ustawy o promocji zatrudnienia i instytucjach rynku pracy oraz niektórych innych ustaw (Dz.U. z 2014 roku, poz. 598).

31 Szerzej zob. A. Drabek, Profilowanie pomocy dla bezrobotnych jako nowy sposób na walkę z bezrobociem?, „Gdańsko-Łódzkie Roczniki Prawa Pracy i Prawa Socjalnego” 2014, nr 4, s. 19 i n. 
Tego typu rozwiązanie stało się źródłem zgłoszonych w piśmiennictwie wątpliwości co do trafności doboru form pomocy do poszczególnych profili, zwrócono również uwagę, że samo zróżnicowanie zakresu środków przewidzianych dla każdej grupy pomocy może nieść ryzyko naruszenia konstytucyjnej zasady równości wobec prawa ${ }^{32}$.

Pojawia się także pytanie o relację, w jakiej pozostają ze sobą profilowanie pomocy dla bezrobotnych oraz zaklasyfikowanie do jednej z grup bezrobotnych uznanych za będących w szczególnej sytuacji na rynku pracy ${ }^{33}$. Kwestia ta zasługuje niewątpliwie na bardziej szczegółowe analizy w odrębnym opracowaniu.

Pojęcie „dostęp do zatrudnienia” w sposób ewidentny wiąże się z poprzedzającym nawiązanie stosunku pracy etapem rekrutacji pracowników. Mimo braku w polskim prawie przepisu przewidującego expressis verbis, iż obowiązek równego traktowania w zatrudnieniu obejmuje również ten etap ${ }^{34}$, teza ta jest powszechnie akceptowana $\mathrm{w}$ piśmiennictwie ${ }^{35}$. Z pewnością znajduje ona swoje oparcie w unormowaniach ponadnarodowych, choćby w Konwencji MOP nr 111, a także w prawie wtórnym Unii Europejskiej. Dyrektywy 2000/43/WE i 2000/78/WE, określając ramy równego traktowania, odnoszą je bowiem między innymi do ,warunków dostępu do zatrudnienia [...], w tym również kryteriów selekcji i warunków rekrutacji”.

$\mathrm{Na}$ gruncie polskich regulacji zakaz dyskryminacji wobec kandydatów do pracy wywieść można z przyznania prawa do odszkodowania za praktyki dyskry-

32 Ibidem, s. 22.

33 Zdaniem A. Drabek (ibidem, s. 19) wraz z wprowadzeniem koncepcji profilowania zaklasyfikowanie do kategorii bezrobotnych znajdujących się w szczególnej sytuacji na rynku pracy przestało mieć w zasadzie znaczenie dla doboru środków, jakie można w stosunku do takiej osoby zastosować.

34 Za regulację odnoszącą się do tej materii należy uznać jednak art. 23a ustawy z dnia 29 sierpnia 1997 roku o rehabilitacji zawodowej i społecznej oraz zatrudnianiu osób niepełnosprawnych (t.j. Dz.U. z 2011 roku, nr 127, poz. 721 z późn. zm.). Przepis ten nakłada na pracodawcę obowiązek zapewnienia niezbędnych racjonalnych usprawnień dla osoby niepełnosprawnej, m.in. uczestniczącej w procesie rekrutacji. Niedokonanie tych usprawnień uważa się za naruszenie zasady równego traktowania w zatrudnieniu. Unormowanie to, obowiązujące od 2011 roku, wprowadzono do polskiego porządku prawnego w celu implementacji art. 5 dyrektywy 2000/78/WE. Szerzej zob. M. Paluszkiewicz, Obowiazek pracodawcy zapewnienia osobie niepetnosprawnej niezbędnych racjonalnych usprawnień, [w:] Wspótczesne problemy prawa emerytalnego, pod red. T. Bińczyckiej-Majewskiej, M. Włodarczyka, Warszawa 2015, s. 309 i n.; A. Ludera-Ruszel, Dyskryminacja ze względu na niepetnosprawność $w$ dostęie do zatrudnienia, „Praca i Zabezpieczenie Społeczne” 2014, nr 8, s. $23-24$.

35 Zob. m.in. Z. Góral, Swoboda doboru pracowników i wolności pracy, [w:] Polskie prawo $w$ okresie transformacji w oświetleniu prawa wspólnotowego, pod red. H. Lewandowskiego, Warszawa 1997, s. 13; M. Tomaszewska, op. cit., s. 129; P. Korus, [w:] Kodeks pracy. Komentarz, pod red. A. Sobczyka, Warszawa 2014, s. 61; Kodeks pracy. Komentarz, pod red. L. Florka, s. 120. 
minacyjne „osobie, wobec której pracodawca naruszył zasadę równego traktowania w zatrudnieniu" (art. $183^{\mathrm{d}}$ k.p.). Oznacza to, że ze stosownym roszczeniem może wystąpić nie tylko pracownik, ale też osoba ubiegająca się o zatrudnienie, którego jej odmówiono w efekcie praktyk dyskryminacyjnych.

O stosowaniu omawianego zakazu w odniesieniu do kandydatów do pracy świadczą również regulacje zawarte w ustawie o promocji zatrudnienia. Należy tu wskazać na art. 36 ust. 5e uzależniający przyjęcie przez urząd pracy oferty pracy składanej przez pracodawcę od tego, czy jest ona wolna od kryteriów dyskryminujących kandydata do pracy, oraz na art. 123 uznający za wykroczenie odmowę zatrudnienia kandydata na wolnym miejscu zatrudnienia (lub przygotowania zawodowego) ze względu na wskazane w tym przepisie kryteria dyskryminacyjne.

Powołane wyżej unormowania ustawy o promocji zatrudnienia uwypuklają dodatkowo znaczenie, jakie dla realizacji zasady równego traktowania w zatrudnieniu na omawianej tu płaszczyźnie ma prawidłowa, niezawierająca wymogów o charakterze dyskryminacyjnym, treść ofert pracy. Dotyczy to także ogłoszeń wykorzystywanych przez pracodawców jako metodę rekrutacji pracowników ${ }^{36}$.

Niestety, praktyka dowodzi ${ }^{37}$, że pracodawcy nie zawsze we właściwy sposób formułują wymagania stawiane kandydatom do pracy, zamieszczając w ofertach pracy czy ogłoszeniach rekrutacyjnych kryteria odpowiadające kryteriom dyskryminacji wskazanym $\mathrm{w}$ art. $18^{3 \mathrm{a}} \S 1 \mathrm{k} . \mathrm{p}$. Niekiedy pojawiają się również wymagania określane mianem kryteriów pozaustawowych, takie jak posiadanie własnych narzędzi pracy, stan rodzinny czy miejsce zamieszkania ${ }^{38}$.

Rozbudowywanie kryteriów dyskryminacyjnych w ofertach pracy nie jest przy tym wyłącznie polską ,,specjalnością”. W piśmiennictwie pojawiły się informacje o szerzącej się ostatnio w USA praktyce ofert zatrudnienia, w których od kandydatów wymaga się pozostawania aktualnie w zatrudnieniu. Prowadzi to do stygmatyzowania bezrobotnych i zmniejszania ich szans na zatrudnienie ${ }^{39}$.

Nie zawsze jednak stawianie kandydatowi do pracy wymagań, które odpowiadają kryteriom dyskryminacyjnym będzie prowadzić do naruszenia zakazu dyskryminacji na etapie rekrutacji. Jeśli bowiem określone kryterium stanowi, ze względu na rodzaj pracy lub warunki jej wykonywania, rzeczywiste, decy-

${ }^{36}$ Zob. P.K. Wacławska, Rekrutacja $w$ drodze ogłoszeń - charakterystyka prawna, „Praca i Zabezpieczenie Społeczne" 2004, nr 4, s. 14 i n.

37 Zob. S.W. Ciupa, Naruszenie zakazu dyskryminacji w praktyce korzystania z ogłoszeń rekrutacyjnych, cz. 1, „Monitor Prawa Pracy” 2006, nr 11, s. 580 i n.; idem, Naruszenie zakazu dyskryminacji w praktyce korzystania z ogłoszeń rekrutacyjnych, cz. 2, „Monitor Prawa Pracy” 2006, nr 12, s. 651 i n.

${ }_{38}$ Idem, Naruszenie zakazu dyskryminacji..., cz. 1, s. 582.

39 J. Jończyk (oprac.), W czasopismach, „Praca i Zabezpieczenie Społeczne” 2015, nr 2, s. 45. 
dujące wymaganie zawodowe stawiane pracownikowi, to niezatrudnienie osoby niespełniającej danego wymagania nie będzie działaniem naruszającym zasadę równego traktowania $\mathrm{w}$ zatrudnieniu (art. $18^{3 \mathrm{~b}} \S 2$ pkt 1 k.p.). Podobnie będzie $\mathrm{w}$ razie podejmowania działań w ramach tzw. dyskryminacji pozytywnej (wyrównawczej), o czym stanowi art. $13^{3 \mathrm{~b}} \S 3$ k.p. Jako szczególny przykład można przywołać tu kryterium niepełnosprawności stawiane niekiedy przez pracodawców jako wymaganie wobec osoby ubiegającej się o zatrudnienie. Należy zgodzić się ze stwierdzeniem, że tego rodzaju praktyka nie prowadzi do dyskryminowania osób pełnosprawnych. Celem pracodawcy jest bowiem w tym przypadku chęć skorzystania z uprawnień przysługujących podmiotom zatrudniającym osoby niepełnosprawne, a regulacje, które te uprawnienia przewidują, mają stymulować, przez zachęty finansowe, zatrudnienie tych osób, wyrównując ich szanse na rynku pracy ${ }^{40}$.

Zapewnieniu równego traktowania $\mathrm{w}$ dostępie do zatrudnienia służy niewątpliwie ograniczenie prawa podmiotu zatrudniającego do pozyskiwania informacji o kandydacie na pracownika. Przewidziany w art. $22^{1} \S 1$ k.p. zamknięty katalog informacji, których pracodawca może domagać się od kandydata na pracownika, w pierwszym rzędzie służyć ma ochronie jego prawa do prywatności. Świadczy o tym choćby to, że bezpośrednim powodem wprowadzenia art. $22^{1}$ do Kodeksu pracy była potrzeba dostosowania prawa pracy do art. 51 Konstytucji RP, w myśl którego nikt nie może być obowiązany inaczej niż na podstawie ustawy do ujawnienia informacji dotyczących jego osoby. Jednakże konieczność uregulowania kwestii zakresu prawa pracodawcy do zadawania pytań ubiegającym się o zatrudnienie była niewątpliwie uwarunkowana również ochroną przed możliwą dyskryminacją w nawiązaniu stosunku pracy ${ }^{41}$.

Jak wynika $\mathrm{z}$ art. $22^{1}$ k.p., uprawnienie pracodawcy do informacji dotyczy sfery identyfikacji personalnej i sfery pracy ${ }^{42}$. Do pierwszej z nich należy między innymi informacja o dacie urodzenia osoby ubiegającej się o zatrudnienie, co umożliwia pracodawcy ustalenie wieku kandydata do pracy. Może stać się to, potencjalnie, powodem decyzji mającej charakter dyskryminacyjny (odmowa zatrudnienia ze względu na wiek). Nie oznacza to jednak, że wiek osoby ubiegającej się o zatrudnienie nie może być uznany za obiektywną przyczynę podjęcia przez pracodawcę takiej decyzji. Jest ona bowiem uzasadniona wówczas, gdy wiek, ze względu na rodzaj działalności zawodowej lub warunki jej wykonywania, stanowi istotne i determinujące wymaganie zawodowe ${ }^{43}$.

40 P.K. Wacławska, op. cit., s. 17.

41 Zob. M. Gersdorf, [w:] M. Gersdorf, K. Rączka, M. Raczkowski, op. cit., s. 168.

42 M. Tomaszewska, op. cit., s. 191.

43 Wyrok Trybunału WE z dnia 12 stycznia 2010 roku w sprawie C-229/08 Colin Wolf. Zob. A.M. Świątkowski, Wiek - obiektywne kryterium różnicowania uprawnień pracowników?, „Przegląd Sądowy" 2001, nr 1, s. 7. 
Mamy w tym przypadku do czynienia z tzw. kontratypem dyskryminacji, a więc nienaruszającym zasady równego traktowania różnicowaniem sytuacji między innymi osób ubiegających się o zatrudnienie. Tej właśnie kategorii dotyczy regulacja zawarta w art. $18^{3 \mathrm{~b}} \S 2$ pkt 1 k.p. „legalizująca” odmowę zatrudnienia pracownika $z$ jednej lub kilku przyczyn określonych $w$ art. $18^{3 a} \S 1$ k.p., jeżeli rodzaj pracy lub warunki jej wykonywania powodują, że przyczyna lub przyczyny wymienione w tym przepisie są rzeczywistym i decydującym wymaganiem zawodowym stawianym pracownikowi.

$\mathrm{Na}$ tle tego przepisu powstaje pytanie, kto decyduje o tym, czy dany rodzaj pracy lub warunki jej wykonywania uzasadniają różnicowanie kandydatów do pracy. W piśmiennictwie słusznie wskazuje się, że decyzja w tym zakresie nie powinna być pozostawiona pracodawcy, lecz powinna znajdować uzasadnienie w przepisach lub być „oczywista” ${ }^{4}$. Tylko przy takim założeniu zostanie ograniczona arbitralność rozstrzygnięć podmiotu zatrudniającego w omawianym zakresie, która nie służyłaby realizacji omawianego przepisu zgodnie z jego celem.

Wzgląd na religię, wyznanie lub światopogląd także może być, zgodnie $\mathrm{z}$ art. $18^{3 \mathrm{~b}} \S 4$ k.p., powodem ograniczenia dostępu do zatrudnienia przez Kościoły i inne związki wyznaniowe oraz organizacje, których etyka opiera się na tych wartościach. Kontratyp ten odnosi się tylko do tej sfery działalności podmiotów wyznaniowych, która ma „zawodowy” charakter i dotyczy sytuacji, kiedy Kościoły oraz związki wyznaniowe są pracodawcami w rozumieniu art. 3 k.p. ${ }^{45}$ Mają one możliwość stawiania osobom ubiegającym się o zatrudnienie wymogów co do wyznawanej religii czy wyznawanego światopoglądu, jeżeli wymogi te stanowią rzeczywiste i decydujące wymagania zawodowe, proporcjonalne do osiągnięcia celu zgodnego $\mathrm{z}$ prawem ${ }^{46}$.

Wracając do kwestii danych wymaganych od kandydata do pracy, należy stwierdzić, że ich zakres może wynikać dodatkowo z przepisów odrębnych, co przewiduje art. $22^{1} \S 4$ k.p. Z uwagi na treść art. 51 Konstytucji należy uznać, że przepisy te muszą mieć rangę ustawy ${ }^{47}$. Danymi tego rodzaju mogą być informacje o posiadaniu pełni praw publicznych czy o niekaralności osoby ubiegającej się o zatrudnienie. W zakresie niekaralności dane te uzyskuje jednak sam pracodawca zgodnie z ustawą z dnia 24 maja 2000 roku o Krajowym Rejestrze Karnym ${ }^{48}$.

44 P. Korus, op. cit., s. 67.

45 M. Tomaszewska, op. cit., s. 149.

46 Szerzej na ten temat zob. J. Ciborowski, Kontratyp od zasady równego traktowania w zatrudnieniu w podmiotach o charakterze wyznaniowym, „Praca i Zabezpieczenie Społeczne” 2010, nr 4, s. 26 i n.

47 J. Stelina, [w:] Kodeks pracy. Komentarz, pod red. A. Sobczyka, s. 96. Zdaniem M. Tomaszewskiej (op. cit., s. 194) za przepisy odrębne należy również uznać rozporządzenie Ministra Pracy i Polityki Socjalnej z dnia 28 maja 1996 roku w sprawie zakresu prowadzenia przez pracodawców dokumentacji w sprawach związanych ze stosunkiem pracy oraz sposobu prowadzenia akt osobowych pracowników (Dz.U., nr 62, poz. 286 z późn. zm.).

48 Dz.U., nr 50, poz. 580 z późn. zm. 
Informacji tej udziela się pracodawcom w zakresie niezbędnym do zatrudnienia pracownika, co do którego z przepisów ustawy wynika wymóg niekaralności, korzystania z pełni praw publicznych, a także uprawnienia do zajmowania określonego stanowiska, wykonywania określonego zawodu lub prowadzenia określonej działalności gospodarczej ${ }^{49}$.

Rozszerzonego względem art. $22^{1} \S 1$ k.p. zakresu danych od kandydata do pracy wymagają w szczególności tzw. pragmatyki pracownicze (np. dotyczące korpusu służby cywilnej, pracowników samorządowych czy pracowników urzędów państwowych). Te dodatkowe informacje stanowią przy tym na gruncie wskazanych przepisów przesłanki, których spełnienie przesądza o możliwości uzyskania statusu pracownika. Ogranicza to wolność jednostki w dostępie do zatrudnienia oraz w wyborze potencjalnego pracodawcy. Powszechnie przyjmuje się jednak, że ograniczenie to uznać należy za uzasadnione ze względu na ochronę interesu publicznego.

Istotne jest niewątpliwie to, aby wprowadzone ustawą dodatkowe wymagania w zakresie dostępu do zatrudnienia były niezbędne ze względu na rodzaj stanowiska lub pracy oraz aby miały obiektywny, podlegający weryfikacji charakter $^{50}$. W kontekście tego ostatniego warunku pewne zastrzeżenia może budzić sposób uregulowania kryterium określanego mianem kwalifikacji moralnych. Przegląd unormowań prawnych przewidujących konieczność legitymowania się przez kandydata do pracy cechą nieskazitelnego charakteru lub nieposzlakowanej opinii daje podstawę do ich krytycznej oceny. Przypadkowość w zakresie objęcia poszczególnych grup pracowniczych wymogiem kwalifikacji moralnych, nieuzasadniona różnorodność stosowanych przez ustawodawcę określeń związanych z tymi kwalifikacjami, a zwłaszcza szczątkowe regulacje procedur weryfikujących sprawdzanie kwalifikacji moralnych budzą obawy co do możliwości naruszenia zasady równości w dostępie do zatrudnienia, a dodatkowo także naruszenia godności i prywatności podmiotów objętych omawianym wymaganiem ${ }^{51}$.

49 Warto zasygnalizować, że w piśmiennictwie wyrażana jest opinia o dopuszczalności pytania kandydata na pracownika o niekaralność również w innych przypadkach niż wskazane w ustawie o Krajowym Rejestrze Karnym. Zob. A. Drozd, Prawo podmiotu zatrudniajacego do pozyskiwania informacji o kandydacie na pracownika, Warszawa 2004, s. 177. Podnosi się także nieadekwatność przyjętej regulacji dla potrzeb minimalizowania ryzyka osobowego pracodawcy. Zob. D. DörreNowak, Refleksje na temat wspótczesnego kształtu ryzyka osobowego pracodawcy oraz prawnie dozwolonych form jego ograniczania, [w:] Współczesne problemy prawa pracy i ubezpieczeń społecznych, pod red. L. Florka, Ł. Pisarczyka, Warszawa 2011, s. 235.

50 W odniesieniu do warunków dostępu do zatrudnienia w administracji publicznej zob. m.in. Prawo urzędnicze. Komentarz, pod red. K.W. Barana, Warszawa 2014; H. Szewczyk, Stosunki pracy $w$ samorzadzie terytorialnym, Warszawa 2012; J. Szczot, Równy dostęp do zatrudnienia w administracji publicznej, Lublin 2014; J. Stelina, Prawo urzędnicze, Warszawa 2013.

51 Zob. B. Mirska, Funkcja ochronna prawa pracy a stosowanie ustawowych wymagań kwalifikacji moralnych wobec kandydatów na pracowników w prawie pracy, [w:] Funkcja ochronna prawa pracy a wyzwania wspótczesności, pod red. M. Bosaka, Warszawa 2014, s. 87. 
6.

Ze względu na to, że formalna koncepcja zasady równości nie gwarantuje faktycznego zrealizowania tej zasady, niezbędne stają się działania służące osiągnięciu równości materialnej (rzeczywistej). Należą do nich tzw. akcje pozytywne, dopuszczone przez ustawodawcę $\mathrm{w}$ art. $18^{3 \mathrm{~b}} \S 3 \mathrm{k} . \mathrm{p}$., a polegające de facto na faworyzowaniu, w celu wyrównania szans, pewnych kategorii pracowników, wyróżnionych ze względu na przyczyny określone w art. $18^{3 \mathrm{a}} \S 1$ k.p.

Polska regulacja $\mathrm{w}$ tej materii wzorowana jest niewątpliwie na prawie unijnym, w którym już dyrektywą 76/207/EWG dopuszczono działania pozytywne w celu wyrównania szans kobiet na rynku pracy. Kwestiom tym wiele uwagi poświęcił również Trybunał Sprawiedliwości Unii Europejskiej (sprawy Kalanke, Marshall, Badeck), a o randze omawianych działań w odniesieniu do eliminowania nierówności między kobietami i mężczyznami świadczy też to, że Traktatem Amsterdamskim akcje pozytywne w tym zakresie uzyskały swoją podstawę w prawie pierwotnym ${ }^{52}$.

Art. $18^{3 \mathrm{~b}} \S 3$ k.p. jest w założeniu adresowany do pracodawcy i to on podejmuje konkretne działania dotyczące wszystkich lub znacznej liczby pracowników, służące wyrównaniu ich szans w zatrudnieniu. Jednakże umocowanie do tych działań znaleźć można w przepisach prawnych, a więc akcje pozytywne w pewnym sensie inicjuje ustawodawca. Przykładem takiej, ,inicjatywy” jest przyznanie osobom niepełnosprawnym pierwszeństwa w zatrudnieniu w urzędach państwowych, korpusie służby cywilnej i samorządzie terytorialnym, którym to regulacjom warto poświęcić nieco więcej uwagi.

Zgodnie ze stosownymi przepisami ${ }^{53}$ pierwszeństwo w zatrudnieniu w urzędach państwowych przysługuje osobom niepełnosprawnym, jeżeli spełniają wymagania na dane stanowisko pracy. Natomiast w korpusie służby cywilnej i w samorządzie terytorialnym ${ }^{54}$ prawo to służy osobom niepełnosprawnym, które w toku naboru znalazły się w gronie pięciu najlepszych kandydatów spełniających wymagania niezbędne oraz w największym stopniu spełniających wymagania do-

52 Szerzej na ten temat zob. A. Ludera-Ruszel, Działania pozytywne jako instrument realizacji zasady równego traktowania kobiet i mężczyzn w zatrudnieniu (analiza polskiego i unijnego prawa pracy), „Annales UMCS. Sectio G” 2015, Vol. LXII, z. 2.

53 Art. 3b ustawy z dnia 16 września 1982 roku o pracownikach urzędów państwowych (t.j. Dz.U. z 2013 roku, poz. 269), art. 29a ustawy z dnia 21 listopada 2008 roku o służbie cywilnej (t.j. Dz.U. z 2014 roku, poz. 1111) i art. 13a ustawy z dnia 21 listopada 2008 roku o pracownikach samorządowych (t.j. Dz.U. z 2014 roku, poz. 1202). Unormowania dotyczące pierwszeństwa w zatrudnieniu zostały wprowadzone do tych ustaw mocą ustawy z dnia 19 sierpnia 2011 roku o zmianie ustawy o służbie cywilnej oraz niektórych innych ustaw (Dz.U., nr 201, poz. 1183).

${ }_{54} \mathrm{~W}$ jednostkach samorządu terytorialnego regułą pierwszeństwa objęte są stanowiska urzędnicze, z wyłączeniem kierowniczych stanowisk urzędniczych, co jest krytykowane w piśmiennictwie. Zob. D. Książek, B.M. Ćwiertniak, [w:] Prawo urzędnicze. Komentarz, pod red. K.W. Barana, s. 549. 
datkowe. Pierwszeństwo, o którym mowa, ma jednak charakter warunkowy, gdyż przysługuje wyłącznie w przypadku, gdy wskaźnik zatrudnienia osób niepełnosprawnych w urzędzie (jednostce samorządu terytorialnego) ${ }^{55}$ jest niższy niż $6 \%$.

Wyznaczenie ram czasowych korzystania przez osoby niepełnosprawne z pierwszeństwa $\mathrm{w}$ zatrudnieniu na moment osiągnięcia określonego wskaźnika zatrudnienia tych osób powoduje, że analizowane tu unormowania uznać można za akcje pozytywne - ich konieczną cechą jest bowiem okresowy charakter działań podejmowanych w celu wyrównania szans. Zasadność prowadzenia tych działań w odniesieniu do osób niepełnosprawnych jest bezsporna, zwłaszcza ze względu na to, że dotyczą one zatrudnienia na otwartym rynku pracy, na którym osoby te stanowią grupę niedostatecznie reprezentowaną.

Przedmiotowe regulacje wpisują się niewątpliwie w zalecane przez Komisję Europejską ${ }^{56}$ przedsięwzięcia, w tym ustawodawcze, których celem jest umożliwienie znacznie większej liczbie osób niepełnosprawnych zarabiania na życie na wolnym rynku. $\mathrm{Z}$ drugiej strony wprowadzenie pierwszeństwa tych osób $\mathrm{w}$ zatrudnieniu w administracji publicznej stało się źródłem wątpliwości co do zgodności przepisów przewidujących to uprawnienie z art. 60 Konstytucji ${ }^{57}$. Powstaje bowiem pytanie, czy w świetle unormowania przewidującego jednakowe zasady dostępu do służby publicznej dopuszczalne jest różnicowanie osób ubiegających się o przyjęcie do tej służby. W piśmiennictwie zwraca się uwagę na to, że pojęcie ,jednakowe zasady” jest niesłusznie utożsamiane ze sformułowaniem „na zasadach równości" ${ }^{58}$. O ile bowiem zgodna z zasadą równości jest możliwość różnego traktowania podmiotów różnych, tj. tych, które nie posiadają wspólnej cechy istotnej, o tyle już pojęcie jednakowych zasad uniemożliwia wprowadzenie jakichkolwiek przesłanek różnicowania osób ubiegających się o zatrudnienie w służbie publicznej ${ }^{59}$. Przemawiałoby to za uznaniem przepisów przewidujących pierwszeństwo osób niepełnosprawnych w zatrudnieniu w administracji publicznej za niezgodne z art. 60 Konstytucji. Jednakże moim zdaniem uznanie oma-

55 Wartość tego wskaźnika w urzędach państwowych przyjmuje się z miesiąca poprzedzającego miesiąc, w którym następuje zatrudnienie, zaś w urzędach zatrudniających członków korpusu służby cywilnej i w jednostkach samorządu terytorialnego - z miesiąca poprzedzającego datę upublicznienia ogłoszenia o naborze.

56 Komunikat KE „Europejska strategia w sprawie niepełnosprawności 2010-2020: Odnowione zobowiązanie do budowania Europy bez barier”. Zob. A. Ludela-Ruszel, Dyskryminacja ..., s. 25.

57 Szerzej na ten temat: B. Przywora, Czy przystugujace osobom niepetnosprawnym preferencje w zatrudnieniu w administracji sa zgodne z konstytucja?, „Przegląd Sejmowy” 2013, nr 4, s. 164.

58 M. Jabłoński, Prawo dostępu do stużby publicznej, [w:] Prawa i wolności obywatelskie w Konstytucji RP, pod red. B. Banaszaka, A. Preisnera, Warszawa 2002, s. 627.

59 Ibidem. Zdaniem B. Przywory (op. cit., s. 155) art. 60 Konstytucji stanowi lex specialis w stosunku do zasady równości z art. 32 Konstytucji, konkretyzując tę zasadę i nadając jej, w zakresie dostępu do służby publicznej, szczególny sens, inny niż rozumienie zasady z art. 32 ustawy zasadniczej. 
wianego uprzywilejowania za akcję wyrównującą szanse uwalnia te regulacje od zarzutu naruszenia wskazanego wyżej przepisu ustawy zasadniczej ${ }^{60}$. W uzasadnieniu do wyroku z dnia 10 maja 2000 roku $^{61}$ Trybunał Konstytucyjny stwierdził, że ustawodawca przy ustalaniu reguł dostępu do służby publicznej powinien uwzględniać „zasady i wartości określone w innych przepisach konstytucyjnych, w tym zasadę sprawiedliwości społecznej (art. 2)". Wyrównywanie szans osób niepełnosprawnych w dostępie do zatrudnienia jest bez wątpienia zgodne z zasadą sprawiedliwości społecznej, tym samym za konstytucyjnie dopuszczalne należy uznać ograniczenie innych osób w korzystaniu z prawa przewidzianego w art. 60 ustawy zasadniczej.

Trudno natomiast moim zdaniem o analogiczną konkluzję w ocenie innej regulacji przewidującej pierwszeństwo w zatrudnieniu, zawartej w art. 26 ust. 3 ustawy o służbie cywilnej. Przysługuje ono na podstawie tego przepisu niektórym kategoriom osób zwolnionych z zawodowej służby wojskowej ${ }^{62} \mathrm{w}$ razie naboru kandydatów do korpusu służby cywilnej na stanowiska związane z obronnością kraju. Pierwszeństwo to ma uzasadniać szczególny charakter wykształcenia, doświadczenie wojskowe i wiedza specjalistyczna, co powoduje, że kwalifikacje te na stanowiskach pracy związanych z obronnością są szczególnie przydatne ${ }^{63}$.

Oceniając unormowania dotyczące pierwszeństwa w zatrudnieniu przewidziane w ustawie o służbie cywilnej wyrażono w piśmiennictwie zapatrywanie, że ustawodawca, kierując się określoną aksjologią, może wprowadzać odstępstwa od równości, rozumianej jako identyczność stawianych wobec kandydatów wymagań i stosowanych standardów, stanowiącej gwarancję prawdziwej otwartości i konkurencyjności procedury rekrutacyjnej ${ }^{64}$. Odstępstwa te, jak stwierdzono, muszą być jednak uzasadnione.

Niewykluczone, że uzasadnienia dla pierwszeństwa w zatrudnieniu osób zwolnionych z zawodowej służby wojskowej należy poszukiwać w zawartym zarówno w Konstytucji (art. 153), jak i w ustawie o służbie cywilnej (art. 1) wymaganiu zawodowego wykonywania zadań państwa przez członków korpusu służby cywilnej. Określenie to oznacza nie tylko „konieczność zatrudnienia osób, które traktują wykonywanie tych zadań jako zawód"65, ale również ma inne znaczenie, które najlepiej oddaje słowo „fachowe” ${ }^{\text {"66 }}$. Kompetencje merytoryczne kandydata do pracy, mierzone poziomem jego wiedzy, doświadczenia i umiejętności, po-

${ }^{60}$ Tak również B. Przywora, op. cit., s. 164.

${ }^{61} \mathrm{~K} 21 / 99$, OTK 2000, nr 4, poz. 109.

${ }_{62}$ Zob. art. 119 ust. 1 ustawy z dnia 11 września 2003 roku o służbie wojskowej żołnierzy zawodowych (t.j. Dz.U. z 2010 roku, nr 90, poz. 593 z późn. zm.).

${ }_{63}$ Art. 119 ust. 2 cytowanej wyżej ustawy.

64 J. Stelina, [w:] Prawo urzędnicze. Komentarz, pod red. K.W. Barana, s. 121.

65 Wyrok TK z dnia 13 listopada 2003 roku, K 51/02, OTK-A 2003, nr 8, poz. 86.

66 Z. Góral, [w:] Prawo urzędnicze. Komentarz, pod red. K.W. Barana, s. 30. 
winny więc niewątpliwie decydować o przydatności do pracy w służbie cywilnej, w szczególności na określonym stanowisku.

Powyższe przemawiałoby za zasadnością uczynionego przez ustawodawcę wyjątku od jednakowych zasad dostępu do służby publicznej, lecz - moim zdaniem - zastrzeżenia budzi sposób jego ukształtowania. Zawarta w ustawie o służbie cywilnej regulacja bazuje bowiem na przyjętym a priori założeniu, że byli żołnierze zawodowi w każdym przypadku dysponują najlepszymi kwalifikacjami do świadczenia pracy na określonych stanowiskach. Wyłącza to całkowicie, w razie naboru na te stanowiska, możliwość konkurowania z nimi innych osób, które - czego nie można wykluczyć - dysponują porównywalnymi kompetencjami merytorycznymi.

„Mechaniczność” uprzywilejowania omawianej kategorii osób razi tym bardziej, gdy porównamy unormowanie dotyczące tej grupy ze sposobem uregulowania pierwszeństwa w zatrudnieniu osób niepełnosprawnych. Osoba niepełnosprawna uczestniczy bowiem w postępowaniu konkursowym na ogólnych zasadach, a z uprzywilejowanego statusu może skorzystać dopiero wtedy, gdy znajdzie się w grupie pięciu najlepszych kandydatów.

Taki kształt regulacji pierwszeństwa w zatrudnieniu dla byłych żołnierzy zawodowych rodzi pytanie o to, czy spełnia ona test konstytucyjności ograniczenia prawa innych osób do korzystania $\mathrm{z}$ dostępu do służby cywilnej na jednakowych zasadach. Wątpliwość dotyczy przede wszystkim tego, czy ustawodawca, wprowadzając ograniczenie prawa, wybrał środek najmniej uciążliwy, do czego jest obowiązany ze względu na przewidziane w art. 31 ust. 3 Konstytucji kryterium konieczności zastosowania ograniczenia ${ }^{67}$. Wątpliwość powyższą należy moim zdaniem rozstrzygnąć na niekorzyść ustawodawcy. Uważam, że cel w postaci obsadzania stanowisk związanych z obronnością kraju osobami posiadającymi najlepsze kompetencje merytoryczne byłby możliwy do osiągnięcia również przy zastosowaniu środka nakładającego mniejsze ograniczenia na prawa innych podmiotów.

Rozważania na temat pierwszeństwa w zatrudnieniu warto uzupełnić o jeszcze jedną uwagę natury ogólnej dotyczącą źródła przyznania tego uprawnienia. $\mathrm{Na}$ akceptację zasługuje wyrażony w piśmiennictwie pogląd, że prawa pierwszeństwa w zatrudnieniu nie mogą kreować postanowienia układów zbiorowych pracy $^{68}$. Układ nie może bowiem naruszać praw osób trzecich (art. $240 \S 3$ k.p.), a za takie osoby można uznać kandydatów do pracy. W związku z tym zawarte $\mathrm{w}$ układzie zbiorowym pracy postanowienie o pierwszeństwie $\mathrm{w}$ zatrudnieniu przysługującym np. dzieciom pracowników należy uznać za dyskryminujące osoby ubiegające się o zatrudnienie.

67 Zob. L. Garlicki, Przesłanki ograniczania konstytucyjnych praw $i$ wolności (na tle orzecznictwa Trybunału Konstytucyjnego), „Państwo i Prawo” 2001, nr 10, s. 20.

68 M. Gładoch, [w:] Kodeks pracy. Komentarz, pod red. A. Sobczyka, s. 788. 
Jedną z najczęściej występujących przesłanek dyskryminacji jest płeć. Na płaszczyźnie zatrudnienia dyskryminacja ze względu na to kryterium dotyka niemal wyłącznie kobiet. Teza ta znajduje potwierdzenie nie tylko w danych statystycznych $^{69}$, ale także w randze, jaką kwestii przeciwdziałania nierównemu traktowaniu kobiet i mężczyzn w zatrudnieniu nadano w regulacjach ponadnarodowych, w szczególności w prawie europejskim. Zakaz dyskryminacji ze względu na płeć stanowi niewątpliwie jedną z podstawowych zasad nie tylko europejskiego prawa pracy, ale i całego systemu prawnego $\mathrm{UE}^{70}$. Zapisany w art. 141 (119) Traktatu Rzymskiego (obecnie art. 157 Traktatu o funkcjonowaniu Unii Europejskiej) nakaz równego traktowania kobiet i mężczyzn w zakresie wynagradzania za pracę, przez rozszerzającą wykładnię Trybunału Sprawiedliwości, przerodził się w nakaz równego traktowania obejmujący swym zakresem także dostęp do zatrudnienia i warunki pracy ${ }^{71}$. Kwestie te stały się przedmiotem unormowań zawartych w prawie wtórnym, wyznaczającym standardy antydyskryminacyjnych regulacji w państwach członkowskich, w tym również w naszym kraju. To właśnie od przepisów dotyczących równego traktowania kobiet i mężczyzn, wprowadzonych w 2001 roku $^{72}$ do Kodeksu pracy (dział pierwszy, rozdział IIa), rozpoczął się proces szczegółowego normowania materii równego traktowania pracowników.

${ }_{69}$ Na przykład Sprawozdanie w sprawie równości kobiet i mężczyzn w Unii Europejskiej - $2012 r$. potwierdza m.in. stale istniejące różnice w wynagrodzeniu za pracę między kobietami i mężczyznami na terenie UE; średnio w 2012 roku różnica ta wynosiła 16,2\%. Wskaźniki zatrudnienia kobiet i mężczyzn w wieku 20-64 lat wynosiły odpowiednio 62,4\% i 74,6\%. Zatrudnieniem w niepełnym wymiarze czasu pracy objętych było $8,4 \%$ mężczyzn i $32 \%$ kobiet, z czego $24 \%$ kobiet podjęło niedobrowolnie pracę w niepełnym wymiarze. Kobiety stanowiły jedynie $16,6 \%$ członków zarządów wielkich przedsiębiorstw notowanych na giełdzie (przy założeniu, że do 1 stycznia 2020 roku wskaźnik ten musi osiągnąć przynajmniej 40\%). Zob. Sprawozdanie w sprawie równości kobiet i mężczyzn w Unii Europejskiej - 2012 r., www.europarl.europa.eu/sides/getDoc.do?pubRef=-// EP//TEXT+REPORT+A7-2014-0073+0+DOC+XML+V0//PL [data dostępu: 10.10.2015].

70 Zob. L. Mitrus, Rozwój prawa wspólnotowego w dziedzinie równego traktowania mężczyzn i kobiet w zatrudnieniu, „Praca i Zabezpieczenie Społeczne” 2007, nr 1, s. 2; L. Florek, Europejskie prawo pracy, Warszawa 2010, s. 58.

71 Zob. A. Szczerba-Zawada, Zasada równego traktowania kobiet i mężczyzn w zakresie dostępu do zatrudnienia oraz warunków pracy w świetle orzecznictwa Trybunału Sprawiedliwości Unii Europejskiej, „Studia Iuridica Toruniensia” 2011, t. IX, s. 230.

72 Ustawa z dnia 24 sierpnia 2001 roku o zmianie ustawy - Kodeks pracy oraz o zmianie niektórych innych ustaw (Dz.U., nr 128, poz. 1406). Natomiast nowelą z dnia 14 listopada 2003 roku o zmianie ustawy - Kodeks pracy oraz o zmianie niektórych innych ustaw (Dz.U., nr 213, poz. 2081) zakresem regulacji rozdziału IIa działu pierwszego objęte zostały także inne niż płeć zakazane kryteria dyskryminacji. W związku z tym tej części unormowań Kodeksu pracy nadano tytuł „Równe traktowanie w zatrudnieniu” w miejsce poprzednio obowiązującego „Równe traktowanie kobiet i mężczyzn". 
Jak zauważono w piśmiennictwie, równe traktowanie oznacza w tym przypadku identyczne traktowanie, oparte na założeniu, że kobiety i mężczyźni w sprawach zatrudnienia są tacy sami. W konsekwencji tego odrębności psychofizyczne kobiety nie powinny stanowić uzasadnienia dla regulacji prawnych odrębnych dla kobiet, z wyjątkiem dotyczącym biologicznego macierzyństwa (ciąża, poród, połóg, karmienie piersią) $)^{73}$.

Takie samo stanowisko zajmuje w tej kwestii Trybunał Sprawiedliwości, przyjmując, że odstępstwa od jednakowego traktowania kobiet i mężczyzn są dopuszczalne wyłącznie ze względu na ciążę i macierzyństwo ${ }^{74}$. Takie założenie, $\mathrm{w}$ odniesieniu do analizowanej w niniejszym opracowaniu kwestii dostępu do zatrudnienia, implikuje pytanie o zgodność ze standardami wynikającymi z prawa unijnego regulacji zawartej w art. 176 k.p. i w wydanym na jego podstawie rozporządzeniu ${ }^{75}$. Przewidziany w art. 176 k.p. zakaz zatrudniania kobiet przy pracach szczególnie uciążliwych lub szkodliwych dla zdrowia dotyczy bowiem wszystkich kobiet, a aspekt związany z macierzyństwem (ciąża, karmienie dziecka piersią) przesądza jedynie o zakresie przedmiotowym tego zakazu. Przepisy rozporządzenia wykonawczego określają więc prace wzbronione ${ }^{76}$ wszystkim kobietom, prace wzbronione kobietom w ciąży lub w okresie karmienia piersią. Za szkodliwe dla zdrowia wszystkich kobiet zostały uznane prace związane z wysiłkiem fizycznym, transportem ciężarów oraz - z określonymi wyjątkami - prace pod ziemią we wszystkich kopalniach.

W piśmiennictwie wskazano na konieczność rozważenia, czy obowiązujący wykaz prac uznanych za szczególnie uciążliwe lub szkodliwe dla zdrowia kobiet nie jest zbyt obszerny i oderwany od indywidualnych możliwości wykonywania

73 T. Liszcz, Równość kobiet i mężczyzn w znowelizowanym kodeksie pracy, „Praca i Zabezpieczenie Społeczne" 2002, nr 2, s. 2.

74 Jednakże ciąża i macierzyństwo nie mogą uzasadniać gorszego traktowania kobiety, gdyż jak to expressis verbis zapisano w dyrektywie 2006/54 - stanowi to dyskryminację. Dotyczy to również etapu poprzedzającego zatrudnienie - w sprawie Dekker (C 177/88) Trybunał Sprawiedliwości uznał, że odmowa przyjęcia do pracy kobiety w ciąży ze względu na jej stan stanowi bezpośrednią dyskryminację ze względu na płeć.

75 Rozporządzenie Rady Ministrów z dnia 10 września 1996 roku w sprawie wykazu prac szczególnie uciążliwych lub szkodliwych dla zdrowia kobiet (Dz.U., nr 114, poz. 5454 z późn. zm.).

${ }^{76}$ Należy zaznaczyć, że określenie „prace wzbronione” nie występuje już w przepisach zarówno kodeksu pracy, jak i rozporządzenia wykonawczego. W tytule tego rozporządzenia oraz w załącznikach zawierających wykazy prac pojęcie to było używane do 2002 roku, a zostało zastąpione nadal stosowanym zwrotem ,,prace szczególnie uciążliwe lub szkodliwe dla zdrowia kobiet” na mocy rozporządzenia Rady Ministrów z dnia 30 lipca 2002 roku zmieniającego rozporządzenie w sprawie wykazu prac wzbronionych kobietom (Dz.U., nr 127, poz. 1092). Określenie „prace wzbronione kobietom”, jeżeli nie posiada odpowiedniego uzasadnienia względami zdrowia danej kobiety czy warunkami występującymi w konkretnym środowisku pracy, pozostaje w sprzeczności z unijną zasadą równego traktowania kobiet i mężczyzn w dostępie do zatrudnienia. Zob. H. Wierzbińska, Ewolucja regulacji prawnej zatrudniania kobiet pod ziemią w kopalniach, „Państwo i Społeczeństwo” 2010, nr 4, s. 119. 
pracy przez kobiety w konkretnych przypadkach oraz na możliwość postawienia przedmiotowej regulacji zarzutu naruszenia zasady równego traktowania $\mathrm{w}$ zatrudnieniu (równego dostępu kobiet i mężczyzn do zatrudnienia) ${ }^{77}$.

Zarzut ten niewątpliwie można uznać za uzasadniony, uwzględniając stanowisko Trybunału Sprawiedliwości w kwestii dotyczącej powszechnego zakazu zatrudniania kobiet pod ziemią w kopalniach. Zakaz ten znalazł się w porządkach prawnych wielu państw w efekcie ratyfikowania przez nie Konwencji MOP nr 45 z 1935 roku, dotyczącej zatrudnienia kobiet przy pracach pod ziemią we wszelkiego rodzaju kopalniach ${ }^{78}$, oraz Europejskiej Karty Społecznej (art. 8 pkt 4b) z $1961 \mathrm{roku}^{79}$. W przypadku państw-członków UE, związanych jednocześnie dyrektywami równościowymi przewidującymi równe traktowanie kobiet i mężczyzn m.in. w zakresie dostępu do zatrudnienia, prowadziło to do rozdźwięku między regulacjami prawa międzynarodowego i prawa unijnego. Można się więc było spodziewać tego, że prędzej czy później zostaną podjęte działania zmierzające do zakwestionowania zgodności analizowanego tu zakazu z prawem UE.

Krajem, przeciwko któremu Komisja Europejska wniosła w 2003 roku skargę do Trybunału Sprawiedliwości była Austria ${ }^{80}$. W wyroku z dnia 1 lutego 2005 roku $^{81}$ TS uznał, że przepisy prawa krajowego zawierające powszechny zakaz zatrudniania kobiet pod ziemią w kopalniach są sprzeczne z dyrektywą 76/207. Tym samym Trybunał nie uznał zasadności odstępstw od równego traktowania kobiet i mężczyzn z innych względów niż ciąża i macierzyństwo.

Wyrok Trybunału Sprawiedliwości z dnia 1 lutego 2005 roku przesądził o tym, że również polskie przepisy przewidujące powszechny zakaz pracy kobiet $\mathrm{w}$ kopalniach pod ziemią są sprzeczne z zasadą równego traktowania kobiet i mężczyzn $\mathrm{w}$ dostępie do zatrudnienia ${ }^{82}$. Wprowadzenie stosownych zmian $\mathrm{w}$ tym zakresie

77 A. Dubowik, Zakazy zatrudniania kobiet i modyfikacje warunków pracy pracownic w ciąży, [w:] Aktualne zagadnienia prawa pracy i polityki socjalnej (zbiór studiów), pod red. B.M. Ćwiertniaka, Sosnowiec 2013, s. 352. Zob. również: K. Walczak, Szczególna ochrona czy bezwzględna równość - dylematy zwiazane z dopuszczeniem kobiet do prac tradycyjnie uznanych za męskie, „Monitor Prawa Pracy” 2008, nr 4, s. 177 i n.

78 Ratyfikowana przez Polskę dnia 23 maja 1957 roku.

79 Ratyfikowana przez Polskę dnia 25 czerwca 1997 roku.

80 Warto dodać, że regulacje obowiązujące w tym kraju w przedmiotowym zakresie były od 2001 roku porównywalne z polskimi przepisami, co dawało podstawę do przyjęcia, że wyrok TS w sprawie Austrii będzie mieć zasadnicze znaczenie po akcesji Polski do Unii Europejskiej w zakresie kształtu polskich unormowań. Zob. H. Wierzbińska, op. cit., s. 116-117.

81 C-203/03.

82 W marcu 2007 roku Komisja Europejska skierowała do Polski na podstawie art. 226 TWE (258 TfUE) zarzuty formalne (wezwanie do usunięcia uchybień), zwracając uwagę na istniejący w Polsce zakaz zatrudniania kobiet w kopalniach pod ziemią, który - jej zdaniem - stanowi przeszkodę w zapewnieniu równego traktowania pracowników, bez względu na płeć, w dostępie do zatrudnienia. Zob. H. Wierzbińska, op. cit., s. 125. 
musiało być jednak poprzedzone wypowiedzeniem przez Polskę Konwencji nr $45^{83}$ oraz uwolnieniem się od zobowiązania wynikającego z art. 8 pkt 4b EKS. Do wypowiedzenia Konwencji $\mathrm{nr} 45$ doszło 28 maja 2008 roku $^{84}$, zaś 5 marca 2010 roku uchwalono ustawę o zmianie zakresu obowiązywania Europejskiej Karty Społecznej z 1961 roku $^{85}$, co otworzyło drogę do wypowiedzenia art. 8 pkt 4b EKS.

W następstwie tych działań zostały podjęte prace legislacyjne, których celem jest zmiana treści art. 176 k.p. oraz rozporządzenia wykonawczego wydanego na podstawie tego przepisu. Projekt nowelizacji Kodeksu pracy z dnia 24 marca 2015 roku $^{86}$ przewiduje objęcie zakazem wykonywania prac uciążliwych, niebezpiecznych lub szkodliwych dla zdrowia wyłącznie kobiet w ciąży i karmiących piersią. W sposób odpowiadający wymaganiom (art. 92 ust. 1 Konstytucji) dla upoważnienia zawartego w ustawie został określony również zakres spraw przekazanych do uregulowania w akcie wykonawczym oraz wytyczne dotyczące jego treści ${ }^{87}$. Uchwalenie proponowanej zmiany niewątpliwie uwolniłoby Polskę od zarzutu niewywiązywania się ze zobowiązań wobec Unii Europejskiej w związku z utrzymywaniem generalnego zakazu zatrudnienia kobiet pod ziemią w kopalniach ${ }^{88}$. Projektowana nowelizacja ma oczywiście większy walor niż wyłącznie wyrugowanie z polskiego porządku prawnego przedmiotowego zakazu. Jej przyjęcie doprowadziłoby bowiem do respektowania przez polskie prawo zasady, iż odstępstwa od jednakowego traktowania kobiet i mężczyzn w zatrudnieniu są dopuszczalne wyłącznie ze względu na ciążę i macierzyństwo.

8.

Równość i sprawiedliwość w sposób ewidentny wiążą się z jeszcze jedną wartością - godnością człowieka. To w godności człowieka - przyrodzonej i nie-

83 Co ciekawe, wypowiedzenie tej konwencji już w 1996 roku sugerowała państwom członkowskim Rada Administracyjna Międzynarodowego Biura Pracy, zalecając jednocześnie rozważenie ratyfikacji Konwencji $\mathrm{nr} 176$ dotyczącej bezpieczeństwa i zdrowia w kopalniach z dnia 22 czerwca 1995 roku. Konwencja ta opiera się na nowoczesnych standardach skupiających się na ochronie ryzyka i zarządzaniu nim, zapewniając odpowiednie środki ochrony i prewencji pracownikom kopalni, bez względu na ich płeć. Zob. K. Walczak, op. cit., s. 180. Należy dodać, że Konwencja nr 176 została ratyfikowana przez Prezydenta RP dnia 18 maja 2001 roku i weszła w życie dla Polski dnia 25 czerwca 2001 roku.

${ }^{84}$ Więcej na ten temat zob. H. Wierzbińska, op. cit., s. 123-127; K. Walczak, op. cit.

85 Dz.U., nr 76, poz. 491.

86 UC 104, http://bip.kprm.gov.pl [data dostępu: 10.09.2015].

$87 \mathrm{Na}$ temat niezgodności z Konstytucją upoważnienia zawartego w aktualnie obowiązującym art. 176 k.p. zob. A. Hintz, J. Skoczyński, [w:] Kodeks pracy. Komentarz, pod red. L. Florka, s. $880-881$.

88 Zarzuty takie skierowane zostały do Polski przez Komisję Europejską dnia 14 maja 2009 roku mimo tego, że już przed tą datą doszło do wypowiedzenia Konwencji nr 45. Zob. H. Wierzbińska, op. cit., s. 126. 
zbywalnej, stanowiącej źródło wolności i praw człowieka i obywatela (art. 30 Konstytucji) - znajduje swe uzasadnienie idea równości w prawie. Obydwie wartości mają uniwersalny charakter, obowiązują w sposób absolutny i stanowią podstawę szeroko pojmowanej sprawiedliwości ${ }^{89}$. To właśnie niezbywalna godność człowieka wymaga, aby każda osoba była traktowana przez prawo sprawiedliwie, czyli według jednakowej miary i bezstronnie ${ }^{90}$.

Prawo pracy w sposób oczywisty jest skoncentrowane na godności, a w szczególności godności pracownika jako osoby poszukującej autonomii przez pracę ${ }^{91}$. W sferze związanej z socjalnymi prawami człowieka kluczowe znaczenie dla zapewnienia, stanowiącej istotę godności, autonomii człowieka ma materialna możliwość jej realizacji. Niewątpliwie godnemu życiu pracownika mają służyć regulacje prawa pracy gwarantujące ochronę trwałości zatrudnienia czy określony poziom wynagrodzenia za pracę. Jest oczywiste, że ochrona tej godności powinna obejmować również etap poprzedzający nawiązanie stosunku pracy. Gwarancją realizacji godności w tym przypadku będzie zapewnienie równego i sprawiedliwego dostępu do zatrudnienia.

\section{BIBLIOGRAFIA}

Boruta J., Zakaz dyskryminacji w zatrudnieniu - nowa regulacja prawna, „Praca i Zabezpieczenie Społeczne" 2004, nr 2.

Bura A., Pojmowanie sprawiedliwości w orzecznictwie Trybunału Konstytucyjnego, „Przegląd Sejmowy" 2001, nr 2.

Ciborowski J., Kontratyp od zasady równego traktowania $w$ zatrudnieniu w podmiotach o charakterze wyznaniowym, „Praca i Zabezpieczenie Społeczne” 2010, nr 4.

Ciupa S.W., Naruszenie zakazu dyskryminacji w praktyce korzystania z ogłoszeń rekrutacyjnych, cz. 1, „Monitor Prawa Pracy” 2006, nr 11.

Ciupa S.W., Naruszenie zakazu dyskryminacji w praktyce korzystania z ogłoszeń rekrutacyjnych, cz. 2, „Monitor Prawa Pracy” 2006, nr 12.

Dörre-Nowak D., Refleksje na temat wspótczesnego kształtu ryzyka osobowego pracodawcy oraz prawnie dozwolonych form jego ograniczania, [w:] Wspótczesne problemy prawa pracy i ubezpieczeń społecznych, pod red. L. Florka, Ł. Pisarczyka, Warszawa 2011.

Drabek A., Profilowanie pomocy dla bezrobotnych jako nowy sposób na walkę z bezrobociem?, „Gdańsko-Łódzkie Roczniki Prawa Pracy i Prawa Socjalnego” 2014, nr 4.

Drozd A., Prawo podmiotu zatrudniajacego do pozyskiwania informacji o kandydacie na pracownika, Warszawa 2004.

Dubowik A., Zakazy zatrudniania kobiet i modyfikacje warunków pracy pracownic w ciąży, [w:] Aktualne zagadnienia prawa pracy i polityki socjalnej (zbiór studiów), pod red. B.M. Ćwiertniaka, Sosnowiec 2013.

Florek L., Europejskie prawo pracy, Warszawa 2003.

89 Zob. J. Potrzeszcz, Idea prawa w orzecznictwie polskiego Trybunału Konstytucyjnego, Lublin 2007, s. 162.

90 Wyrok TK z dnia 6 lipca 1999 roku, P 2/99, OTK-ZU 1999, nr 5, poz. 103.

91 A. Sobczyk, op. cit., s. 122. 
Florek L., Europejskie prawo pracy, Warszawa 2010.

Garlicki L., Przestanki ograniczania konstytucyjnych praw $i$ wolności (na tle orzecznictwa Trybunatu Konstytucyjnego), „Państwo i Prawo” 2001, nr 10.

Gersdorf M., [w:] M. Gersdorf, K. Rączka, M. Raczkowski, Kodeks pracy. Komentarz, Warszawa 2014.

Gładoch M., [w:] Kodeks pracy. Komentarz, pod red. A. Sobczyka, Warszawa 2014.

Góral Z., [w:] Prawo urzędnicze. Komentarz, pod red. K.W. Barana, Warszawa 2014.

Góral Z., O kodeksowym katalogu zasad indywidualnego prawa pracy, Warszawa 2011.

Góral Z., Swoboda doboru pracowników i wolności pracy, [w:] Polskie prawo w okresie transformacji w oświetleniu prawa wspólnotowego, pod red. H. Lewandowskiego, Warszawa 1997.

Hintz A., Skoczyński J., [w:] Kodeks pracy. Komentarz, pod red. L. Florka, Warszawa 2011.

Jabłoński M., Prawo dostępu do stużby publicznej, [w:] Prawa i wolności obywatelskie w Konstytucji RP, pod red. B. Banaszaka, A. Preisnera, Warszawa 2002.

Jończyk J. (oprac.), W czasopismach, „Praca i Zabezpieczenie Społeczne” 2015, nr 2.

Kordela M., Zarys systemu aksjologicznego w orzecznictwie Trybunatu Konstytucyjnego, „Studia Prawnicze" 2000, nr 1-2.

Korus P., [w:] Kodeks pracy. Komentarz, pod red. A. Sobczyka, Warszawa 2014.

Książek D., Ćwiertniak B.M., [w:] Prawo urzędnicze. Komentarz, pod red. K.W. Barana, Warszawa 2014.

Liszcz T., Równość kobiet i mężczyzn w znowelizowanym kodeksie pracy, „Praca i Zabezpieczenie Społeczne" 2002, nr 2.

Liszcz T., W sprawie sprawiedliwości w prawie pracy, [w:] Aksjologiczne podstawy prawa pracy i ubezpieczeń społecznych, pod red. M. Skąpskiego, K. Ślebzaka, Poznań 2014.

Ludera-Ruszel A., Dyskryminacja ze względu na niepetnosprawność w dostępie do zatrudnienia, „Praca i Zabezpieczenie Społeczne” 2014, nr 8.

Ludera-Ruszel A., Działania pozytywne jako instrument realizacji zasady równego traktowania kobiet i mężczyzn w zatrudnieniu (analiza polskiego i unijnego prawa pracy), „Annales UMCS. Sectio G” 2015, Vol. LXII, z. 2.

Mirska B., Funkcja ochronna prawa pracy a stosowanie ustawowych wymagań kwalifikacji moralnych wobec kandydatów na pracowników w prawie pracy, [w:] Funkcja ochronna prawa pracy a wyzwania wspótczesności, pod red. M. Bosaka, Warszawa 2014.

Mitrus L., Rozwój prawa wspólnotowego $w$ dziedzinie równego traktowania mężczyzn i kobiet w zatrudnieniu, „Praca i Zabezpieczenie Społeczne” 2007, nr 1.

Nowacki J., Sprawiedliwość a równość w orzecznictwie Trybunału Konstytucyjnego, [w:] W kręgu zagadnień konstytucyjnych. Profesorowi Eugeniuszowi Zwierzchowskiemu w darze, pod red. M. Kudeja, Katowice 1999.

Paluszkiewicz M., Obowiazek pracodawcy zapewnienia osobie niepetnosprawnej niezbędnych racjonalnych usprawnien, [w:] Wspótczesne problemy prawa emerytalnego, pod red. T. Bińczyckiej-Majewskiej, M. Włodarczyka, Warszawa 2015.

Perdeus W., [w:] Kodeks pracy. Komentarz, pod red. K.W. Barana, Warszawa 2014.

Potrzeszcz J., Idea prawa w orzecznictwie polskiego Trybunału Konstytucyjnego, Lublin 2007.

Przywora B., Czy przystugujace osobom niepetnosprawnym preferencje $w$ zatrudnieniu $w$ administracji są zgodne z konstytucją?, „Przegląd Sejmowy” 2013, nr 4.

Rawls J., Teoria sprawiedliwości, Warszawa 1994.

Rączka K., [w:] M. Gersdorf, K. Rączka, M. Raczkowski, Kodeks pracy. Komentarz, Warszawa 2014.

Serafin K., Zasada równego traktowania w zakresie dostępu do usług i instrumentów rynku pracy, [w:] Bezrobocie i polityka zatrudnienia, pod red. Z. Górala, Warszawa 2013.

Sobczyk A., Prawo pracy w świetle Konstytucji RP, t. 1, Warszawa 2013.

Sprawozdanie w sprawie równości kobiet i mężczyzn w Unii Europejskiej - 2012 r., www.europarl.europa.eu/sides/getDoc.do?pubRef=-//EP//TEXT+REPORT+A7-2014-0073+0+$\mathrm{DOC}+\mathrm{XML}+\mathrm{V} 0 / / \mathrm{PL}$ [data dostępu: 10.10.2015].

Stelina J., [w:] Kodeks pracy. Komentarz, pod red. A. Sobczyka, Warszawa 2014. 
Stelina J., [w:] Prawo urzędnicze. Komentarz, pod red. K.W. Barana, Warszawa 2014.

Stelina J., Prawo urzędnicze, Warszawa 2013.

Szczerba-Zawada A., Zasada równego traktowania kobiet i mężczyzn w zakresie dostępu do zatrudnienia oraz warunków pracy w świetle orzecznictwa Trybunatu Sprawiedliwości Unii Europejskiej, „Studia Iuridica Toruniensia” 2011, t. IX.

Szczot J., Równy dostęp do zatrudnienia w administracji publicznej, Lublin 2014.

Szewczyk H., Stosunki pracy w samorzadzie terytorialnym, Warszawa 2012.

Ślebzak K., Antydyskryminacyjne prawo Unii Europejskiej $w$ dziedzinie zatrudnienia $w$ orzecznictwie TSUE - zakres i podstawowe pojęcia, „Praca i Zabezpieczenie Społeczne” 2013, nr 9.

Świątkowski A.M., Wiek - obiektywne kryterium różnicowania uprawnień pracowników?, „Przegląd Sądowy" 2001, nr 1.

Tomaszewska M., [w:] Kodeks pracy. Komentarz, pod red. K.W. Barana, Warszawa 2014.

Wacławska P.K., Rekrutacja w drodze ogłoszeń - charakterystyka prawna, „Praca i Zabezpieczenie Społeczne" 2004, $\mathrm{nr} 4$.

Wagner B., Zasada równego traktowania i niedyskryminacji pracowników, „Praca i Zabezpieczenie Społeczne" 2002, nr 3.

Walczak K., Szczególna ochrona czy bezwzględna równość - dylematy zwiazane z dopuszczeniem kobiet do prac tradycyjnie uznanych za męskie, „Monitor Prawa Pracy” 2008, nr 4.

Wierzbińska H., Ewolucja regulacji prawnej zatrudniania kobiet pod ziemia w kopalniach, „Państwo i Społeczeństwo" 2010, nr 4.

Włodarczyk M., [w:] Ustawa o promocji zatrudnienia i instytucjach rynku pracy. Praktyczny komentarz, pod red. Z. Górala, Warszawa 2011.

Zieliński M.J., Zasada równego traktowania a zakaz dyskryminacji w prawie pracy, „Praca i Zabezpieczenie Społeczne" 2013, nr 8.

Zieliński T., Goździewicz G., [w:] Kodeks pracy. Komentarz, pod red. L. Florka, Warszawa 2011.

Ziembiński Z., Sprawiedliwość społeczna jako pojęcie prawne, Warszawa 1996.

\section{SUMMARY}

The article deals with problem of equality and justice in access to employment. The majority of this study concerns equal treatment the unemployed who need employment exchange and people who take part in selection processes as well. The author presents Polish law regulations which aim is work against discrimination on previous employment stage. The paper shows the importance of positive actions as the instrument for real equality in access to employment. Referring to the sex as one of the discriminations criteria the author points that Polish law rules concerning burdensome and harmful works for women are incompatible with the standards of EU law.

Keywords: access to employment; equal treatments; employment exchange; selection processes; positive actions 